\title{
Impact of Industrial Development on Groundwater \& Surface Water Quality in Industry Dominating Sectors of Chandigarh, India
}

\author{
Simerjit Kaur (Corresponding author) \\ Assistant Professor, Dept of Applied Sciences \\ Rayat-Bahra Institute of Engineering \& Biotechnology, Mohali Campus (Punjab), India \\ E-mail: dr.simer07@yahoo.com
}

Promila Malik

Associate Professor \& Head of the department, Dept of Biotechnology

Post-graduate Govt. college-11, Chandigarh, India

Received: May 2, 2012 Accepted: May 29, 2012 Published: December 1, 2012

doi:10.5296/jee.v3i1.2182ＵRL: http://dx.doi.org/10.5296/jee.v3i1.2182

\begin{abstract}
Physico-chemical analysis was carried out to assess the extent of chemical pollution in surface water \& ground water as affected by industrial effluents in industry dominating sectors in Chandigarh, India. Sampling was done in the month of November, 2011. Both the groundwater $(\mathrm{GW})$ \& surface water (SW) samples collected at selected points were analyzed for temperature, $\mathrm{pH}$, alkalinity, calcium, magnesium, total hardness, dissolved oxygen (DO) \& chemical oxygen demand (COD). It has been observed that decreased $\mathrm{pH} \&$ increased alkalinity make this water unpalatable. Both the GW as well as SW, at all the sampling spots are very hard and cannot be considered suitable for drinking purposes. The levels of calcium \& magnesium were also not within prescribed limits. The lowest level of DO in some sampling spots indicates that industrial activities consume dissolved oxygen present in the water. COD was found to be in acceptability range in SW as well in GW at most of the sampling spots. The results suggested that SW \& GW in most of the sectors is polluted \& not fit for human consumption without treatment. It is therefore recommended that careless disposal of the waste should be discouraged \& if possible, there is need to treat the waste
\end{abstract}




\section{Macrothink}

Journal of Environment and Ecology

ISSN 2157-6092

2012, Vol. 3, No. 1

properly before dumped in to the environment. The values of all the parameters have shown significant variations between $\mathrm{GW} \& \mathrm{SW}$ at $5 \%$ level of significance.

Keywords: Groundwater analysis, Surface water analysis, Industrial effluent, Total hardness, Alkalinity, Calcium concentration, Magnesium concentration, Dissolved oxygen. 


\section{Introduction}

It is estimated that $80 \%$ of domestic needs in rural areas and $50 \%$ in urban areas is met by ground water. India's total replenishable groundwater has been estimated at $431.8 \mathrm{~km}^{3}$ by the

Central Statistical Organization. The average level of groundwater development in India is $32 \%$, although some states have exploited their resources to a much greater extent $(94 \%$ in Punjab, $84 \%$ in Haryana, $60 \%$ in Tamil Nadu, 64\% in Lakshadweep, 51\% in Rajasthan). 85\% of ground water extracted is used for irrigation purposes and $15 \%$ for Industrial and domestic purposes. Reciprocally, as much as 70 to $80 \%$ of India's agricultural output may be groundwater dependent. There are about 2950 Small Scale and 15 Large and Medium Scale Units in existence in Chandigarh as on date. Growth of industry for the last few years has been limited in Chandigarh as it is not an industry led city because of the limited space envisaged for industrial development at the time of original planning of the city. However, still keeping in view the fact that industry would provide crucial resource base in the city, a limited area of about 1450 acres was planned for development as industrial area mainly for the development of small scale and pollution free industries. The Chandigarh city was not planned to be developed as an industrial city hence limited provision was made for industries. As a result of which the industrial growth has been limited. An area of 1,450 acres was planned for development of industrial area mainly for SSI units and pollution free industries. There is not much scope for expansion apart from existing Industrial areas of Phase-I and Phase-II. Out of a total of about 2950 small scale industries in Chandigarh, about $40 \%$ are ancillary units producing components for the major tractor industry around Chandigarh. Light engineering industry is heavily represented, other industrial units produce mainly industrial fasteners, electrical / electronic items, machine tools, pharmaceuticals, plastic goods, sanitary fittings, steel / wooden furniture and food products etc. A number of items manufactured here are finding ready markets abroad. The total estimated annual output of industries is to be tune of Rs. 650.00 crore. The overall picture is that Chandigarh's economy is dominated by industries manufacturing food products or providing repair services, with basic metals and alloys and manufacture of machinery occupying a second rung.

Punjab, Haryana and Himachal Pradesh areas adjacent to the Union Territory have experienced rapid industrial growth and they are having an impact on the Chandigarh industrial scene. Nearly all of these enterprises have their corporate offices in the Union Territory --though technically located outside the Union Territory, these units are functionally part of the city's economy.

While industrial development causes more employment in the region, the possibilities of adverse effects on the environment also increased if these adverse effects are not properly contained or reduced to minimum. Therefore, rapid increase in industrialization has put tremendous pressure on surface water as well as groundwater resources in this area (Lahiry, 1996). The composition and concentration of substances in ground and surface water is a resultant of two factors: the geological structure of the earth's crust, including the intensity with which it is leached, and anthropogenic activity associated with agriculture, industry and public utilities. As water travels through the soil's profile, various water-soluble substances 


\section{Macrothink}

are released (Pulikowski et al. 2006). In recent years, the interest in quality control of water has increased considerably, since water quality interventions have a great influence on human health (Memon et al., 2011; Gadgil 1998; Arain et al. 2008; Dixit and Tiwari 2008). Therefore, studies were initiated to assess the impact of industrialization on water resources by selecting twenty sampling spots in Chandigarh \& adjacent areas.

\section{Research Methods}

\subsection{Description of the Study Area}

Chandigarh is located in the fringes of the Shivalik range at $30^{\circ} 44^{\prime} 14 \mathrm{~N}$ latitude and $76^{\circ} 47^{\prime}$ $14 \mathrm{E}$ longitude. The area falls under the Indo-Gangetic Plain a few miles south of the Shiwalik Hills and between two seasonal hill torrents, the Sukhna Choe and the Patiali Rao. The land is a flat, fertile tract of alluvial soils. It covers an area of approximately114 $\mathrm{km}^{2}$ and shares common boundaries with the states of Haryana in the south and east, and Punjab in the north and west. Chandigarh has a sub-tropical continental monsoon climate characterized by a seasonal rhythm, hot summers, cool winters, unreliable rainfall and great variation in temperature $\left(0^{\circ} \mathrm{C}\right.$ to $\left.44^{\circ} \mathrm{C}\right)$. In winters, frost sometimes occurs during December and January. The average annual rainfall is $104.8 \mathrm{~cm}$. It also receives occasional winter rains from the western disturbance. The best season is between September and November when the sky is crystal clear and mornings and afternoons are delightful.

\subsection{Sampling Stations}

Groundwater \& surface water quality of Chandigarh, India has been assessed to see the suitability of groundwater as well as of surface water for domestic purposes. The groundwater samples from Hand pumps/Bore wells/Tap water were collected in triplicates in the proximity of industrial area for various physico-chemical \& bacteriological parameters for two rounds to ascertain seasonal impacts. The sampling was done in the month of November 2011. The layout of the study area is shown in Fig I. This data was analyzed with reference to WHO (2004) guidelines. 


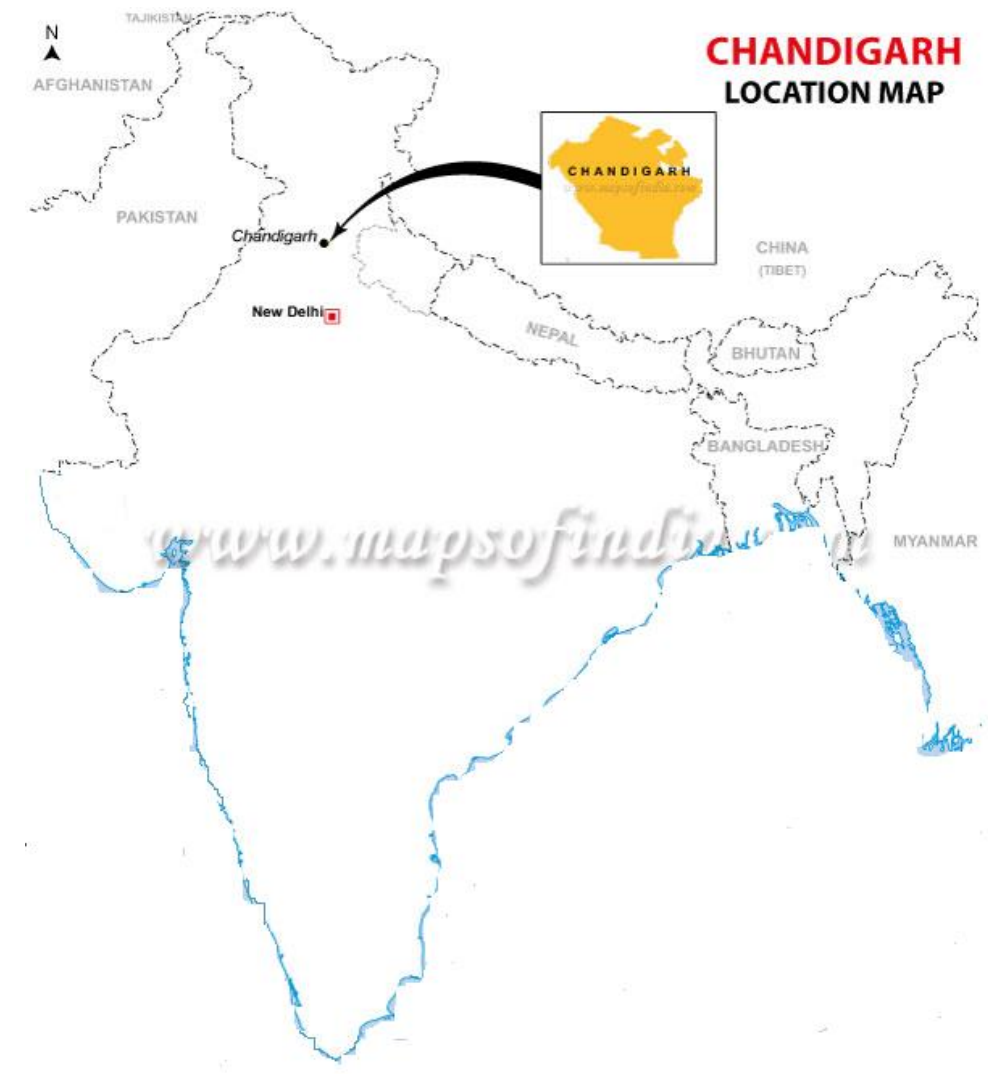

Figure 1. Location of the Study Area

\subsection{Sampling Precautions}

Sample preservation before analysis is very much important as collection of truly representative sample. It is essential to protect the samples from changes in composition and deterioration with ageing due to interactions like redox reactions, microbial activities $\&$ algal growth. All the samples were collected in high grade polyethylene tightly screwed bottles and kept in ice-box at $4{ }^{\circ} \mathrm{C}$ till transported to laboratory for experimentation.

\subsection{Water Analysis}

The methodology adopted for physico-chemical analysis was given by APHA, 2000.

Temperature: Temperature was estimated using a thermometer at the time of the sample collection. The thermometer was dipped in to the water sample, held in the middle for sometime \& temperature reading was noted down.

pH: $\mathrm{pH}$ of the water sample was measured using a $\mathrm{pH}$ meter after calibrating the $\mathrm{pH}$ meter with the buffer solution of $\mathrm{pH} 4.0 \& 9.0$ and then readings were noted down.

Estimation of Alkalinity: Alkalinity was determined volumetrically. In this method, $\mathrm{H}_{2} \mathrm{SO}_{4}$ solution was standardized using standard. $\mathrm{NaOH}$ solution. $25 \mathrm{ml}$ of sample was taken in titration flasks and 2 drops of phenolphthalein was added indicator, titrated against N/50 $\mathrm{H}_{2} \mathrm{SO}_{4}$ solution, until pink colour just disappeared. Recorded volume of acid used as $\mathrm{A} \mathrm{ml}$. To the same solution, added 2-3 drops of methyl orange indicator and titrated against N/50 


\section{IIMacrothink}

$\mathrm{H}_{2} \mathrm{SO}_{4}$ solution, until colour changed from light yellow to red. Recorded volume of acid used in titration with methyl orange as indicator as $B$ ml. Total volume of acid used $=(A+B) m l$.

General Calculations:

Total Alkalinity $\left(\right.$ as $\left.\mathrm{CaCO}_{3}\right)=\mathrm{N} 2 \times \mathrm{V} 2 \times$ eq. Wt. of $\mathrm{CaCO}_{3} \times 1000 / \mathrm{V} 1$

Where, $\mathrm{N} 2=$ Normality of standard $\mathrm{H}_{2} \mathrm{SO}_{4}$,

$\mathrm{V} 2=$ Total volume of acid used $(\mathrm{A}+\mathrm{B}) \mathrm{ml}$. V1= Volume of sample taken.

Estimation of Total Hardness (TH): Estimation of total hardness (TH) is a measure of calcium and magnesium is expressed in terms of ppm was estimated by EDTA titration method given below:

1. Standardization of EDTA solution with standard $\mathrm{CaCo}_{3}$ solution. 2. Titration of test samples: Take $10 \mathrm{ml}$ of sample in titration flask and $2 \mathrm{ml}$ of buffer solution, $4-5$ drops of EBT indicator were added to it. Wine red colour appeared. After that it was titrated it with EDTA solution till wine red colour changed to blue. Recorded the volume of EDTA solutions used.

General calculations:

Total hardness $=\mathrm{A} \times \mathrm{B} \times 1000 / \mathrm{V}$

Where,

$\mathrm{V}=$ volume of sample taken $(\mathrm{ml})$

$\mathrm{A}=$ volume of EDTA used

$\mathrm{B}=\mathrm{mg}$ of $\mathrm{CaCO}_{3}$, equivalent to $\mathrm{ml}$ of $0.01 \mathrm{~m}$ EDTA titrant.

$\left(1 \mathrm{ml}\right.$ of $0.01 \mathrm{~m}$ EDTA $=1 \mathrm{mg}$ of $\left.\mathrm{CaCO}_{3}\right)$

Estimation of Calcium: To $50 \mathrm{ml}$ of the sample, added $1 \mathrm{ml}$ of $1 \mathrm{~N} \mathrm{NaOH}$ and a pinch of Pattern and Reader's regent. It was titrated against EDTA till the colour changed from pink to blue. Final volume of EDTA used was noted down.

General calculation:

$\mathrm{Ca}(\mathrm{mg} / \mathrm{l})=\mathrm{AXB} 400.8 / \mathrm{V}$

Calcium hardness $\left(\mathrm{mgCaCo}_{3}\right)=\mathrm{AXBX} 1000 / \mathrm{V}$

Where,

$\mathrm{A}=$ volume of EDTA used

$\mathrm{B}=\mathrm{mg}$ of $\mathrm{CaCO}_{3}$ equivalent to $1 \mathrm{ml}$ of $0.01 \mathrm{~m}$ EDTA titrant. Standard EDTA titrant $0.01 \mathrm{~m}$ is equivalent to $400.8 \mathrm{ug}$

$\mathrm{V}=$ volume of the sample taken $(\mathrm{ml})$ 
Estimation of Magnesium: Mg was estimated by estimating total hardness and calcium hardness. Therefore, $\mathrm{Mg}$ can be calculated easily by simple calculation from total hardness and calcium hardness as follows:

$\operatorname{Mg}(\mathrm{mg} / \mathrm{l})=($ Total hardness-Calcium hardness $)$ X 0.243

Estimation of Dissolved oxygen (DO): DO was measured by titration method taking into account the following chemicals: $\mathrm{MnSO}_{4}$ solution (dissolved 100.0 grams of $\mathrm{MnSO} 4$ in previously boiled distilled water, made the volume upto $200.0 \mathrm{ml}$ ), $0.025 \mathrm{~N}$ sodium thiosulphate solution (dissolved 6.205 grams of $\mathrm{Na}_{2} \mathrm{~S}_{2} \mathrm{O}_{3}$ in distilled water, made the volume to $1.0 \mathrm{~L}$ by adding distilled water), alkaline iodide solution (dissolved 100.0 grams of $\mathrm{KOH}$ and 50.0 grams of $\mathrm{KI}$ in $200.0 \mathrm{ml}$ of previously boiled water), starch indicator (dissolved 100.0 grams of starch in $100.0 \mathrm{ml}$ of warm distilled water), potassium fluoride solution, concentrated sulphuric acid.

To the water sample filled BOD bottles, added $2.0 \mathrm{ml}$ of $\mathrm{KF}$ solution, $2.0 \mathrm{ml}$ of $\mathrm{MnSO}_{4}$ solution and $2.0 \mathrm{ml}$ of alkaline KI. Bottles were shaken and the precipitates were allowed to settle down. After that, added $2.0 \mathrm{ml}$ of concentrated sulphuric acid, shaken well to dissolve the precipitates. Transferred the contents of the bottles into titration flasks, added few drops of starch indicator to the flask till blue color appeared. This solution was titrated against $\mathrm{Na}_{2} \mathrm{~S}_{2} \mathrm{O}_{3}$ solution until blue color disappeared.

DO was calculated using the following formulae:

$\mathrm{DO}(\mathrm{mg} / \mathrm{L})=8 \mathrm{X} 1000 \mathrm{XNXV} / \mathrm{V}$

Where, $\mathrm{V}=$ Volume of the sample taken in $\mathrm{ml}$

$\mathrm{V}^{\prime}=$ Volume of titrant used in $\mathrm{ml}$

$\mathrm{N}=$ Normality of the titrant

Chemical Oxygen Demand (COD): COD gives the measure of oxygen consumed during the oxidation of the oxidizable organic matter present in a water sample. The following chemicals were used to determine the $\mathrm{COD}$ of a water sample: $0.1 \mathrm{~N} \mathrm{~K}_{2} \mathrm{Cr}_{2} \mathrm{O}_{7}$ solution (dissolved 3.67grams of $\mathrm{K}_{2} \mathrm{Cr}_{2} \mathrm{O}_{7}$ to $1 \mathrm{~L}$ of distilled water), 2M sulphuric acid (dissolved 10.8 concentrated sulphuric acid to $1 \mathrm{~L}$ of distilled water), $0.1 \mathrm{M}$ sodium thiosulphate solution (dissolved 15.811grams of sodium thiosulphate to $2 \mathrm{~L}$ of distilled water), KI solution (dissolved 20grams of $\mathrm{KI}$ in $100 \mathrm{ml}$ of distilled water), $1 \%$ starch solution (dissolved 1.0 grams of starch to $100 \mathrm{ml}$ of distilled water). $50.0 \mathrm{ml}$ of distilled water and $50.0 \mathrm{ml}$ of water samples were taken in two conical flasks, separately. To each flask, poured $5.0 \mathrm{ml}$ of $\mathrm{K}_{2} \mathrm{Cr}_{2} \mathrm{O}_{7}$ solution, incubated the flasks at $1000^{\circ} \mathrm{C}$ for an hour. After cooling for 10 minutes, added $5.0 \mathrm{ml}$ of $\mathrm{KI}$ solution and $10.0 \mathrm{ml}$ of sulphuric acid solution to each flask. Added $1.0 \mathrm{ml}$ of starch solution to each flask till blue color developed. Titrated the solutions in the flask against $0.01 \mathrm{M}$ sodium thiosulphate solution till blue color disappeared completely.

COD was calculated using the following formulae: 
$\mathrm{COD}(\mathrm{mg} / \mathrm{L})=8 \times \mathrm{C} \mathrm{X}(\mathrm{VB}-\mathrm{VA}) / \mathrm{VS}$

\subsection{Data Analysis}

Data was analyzed using SPSS at 5\% level of significance by applying t-test to compare the means as well as differences in the water quality of surface water \& groundwater.

\section{Results \& Discussions}

Temperature: Temperature was ranged from 22 to $27{ }^{\circ} \mathrm{C}$ for surface water and from 20 to $25^{\circ} \mathrm{C}$ for groundwater with maximum temperature observed at Industrial phase-I in surface water as well as groundwater (Fig.2). Temperature has shown considerable variations $(\mathrm{p}<0.05)$ among various sampling spots.

pH: The $\mathrm{pH}$ is the scale of intensity of acidity and alkalinity of water and measures the concentration of hydrogen ions (Kumar et al., 2011). For drinking water, the normal pH range is from 6.5 to 7.0. The surface water was characterized by $\mathrm{pH}$ ranging from 6.4 to 6.8 , a somewhat smaller range from 7.0 to 7.23 , observed for groundwater (Fig.3). On the whole they are neutral or slightly acidic waters.

Alkalinity: Alkalinity is due to presence of salts of weak acids, carbonates, bicarbonates, hydroxides, phosphates \& organic sulphates. It has been observed that the alkalinity levels are much higher in surface water than groundwater ranging from 485 to $1175 \mathrm{mg} / \mathrm{l}$ for surface water and from 400 to $820 \mathrm{mg} / \mathrm{l}$. Alkalinity of surface water is very high in sector-52, industrial phase-I \& industrial phase-II in comparison to groundwater (Fig.4). The levels of alkalinity varied significantly $(\mathrm{p}<0.05)$ between surface water \& groundwater although the levels in sectors-22, $38 \& 42$ did not vary significantly in case of groundwater. Decreased $\mathrm{pH}$ $\&$ increased alkalinity make this water unpalatable.

Total Hardness: The presence of divalent metallic cations like calcium, magnesium, strontium, ferrous iron and manganese ions in the water make it hard. Ferric iron and aluminum ions can also contribute to hardness, but the contribution is normally negligible due to their limited solubility. Hardness in water is also derived from the solution of carbon dioxide released from the bacterial action in soil in percolating water (Sawyer and McCarty, 1967 and Sundaray et al., 2009). Durfer and Backer (1964), has classified the degree of hardness into the following categories: 0 to $60 \mathrm{mg} / \mathrm{l}$ as soft; 60 to $120 \mathrm{mg} / \mathrm{l}$ as moderately hard; 120 to $180 \mathrm{mg} / \mathrm{l}$ as hard and $>180 \mathrm{mg} / \mathrm{l}$ as very hard. The optimum range of hardness in drinking water is from $80-100 \mathrm{mg} / \mathrm{l}$. In areas where drinking water is harder than $500 \mathrm{mg} / \mathrm{L}$, higher incidence rates of gallbladder disease, urinary stones, arthritis and arthropathies (Memon et al., 2011 ; Muzalevskaya et al. 1993), and cancer (Memon et al., 2011; Golubev and Zimin 1994) have been reported.

In present studies, the groundwater as well as surface water at all the sampling spots is very hard and cannot be considered suitable for drinking purposes (Fig.5). Surface water is very hard in sector-52, industrial phase-I \& II followed by sector-35, sector-44, sector-58. Also total hardness of groundwater is more $(\mathrm{p}<0.05)$ in comparison to total hardness of surface 
water in sector-22 \& sector-42. Likewise water is very hard in sector-22, sector-42, industrial phase-I \& II (Fig.5).

Calcium: Calcium can enter the water bodies through rocks. The disposal of sewage and industrial wastes into the water bodies can also lead to accumulation of calcium into them. The limit for calcium as specified by Ayers and Westcot (1994) is 0-20 me/L (mg/L divided by equivalent weight). Groundwater has shown higher concentration of calcium than surface water in all the selected spots. Highest calcium concentration was observed in industrial phase-I ranged from $98-220 \mathrm{mg} / \mathrm{l}$ in groundwater and from $120-240 \mathrm{mg} / \mathrm{l}$ in surface water (Fig.6). Calcium concentration varied significantly $(\mathrm{p}<0.05)$ is not within the prescribed limits in both the cases. The levels of calcium have not shown significant variations in industrial phase-I \& II in surface water $\&$ groundwater.

Magnesium: Magnesium is an essential element in human metabolism and is required for over 300 enzyme reactions including all reactions requiring adenosine triphosphate. Magnesium is required to regulate cell permeability, and inadequate levels of magnesium will severely affect cardiovascular, neuromuscular, and renal functions. The magnesium levels of surface water are higher than groundwater at all the sampling spots ranging from $27-67 \mathrm{mg} / \mathrm{l}$ for surface water \& 23-44mg/l for groundwater (Fig.7). Magnesium concentration in surface water is very high in sector-42, sector-48, industrial phase-I \& industrial phase-II. Groundwater samples have shown increased magnesium concentration in sector-38, sector-41 \& industrial phase-I. Magnesium has shown significant variations $(\mathrm{p}<0.05)$ between surface water \& groundwater.

Dissolved oxygen (DO): The DO in the surface water is important parameter because it indicates the status of biological degradation of sewage by aerobic and anaerobic microorganisms while the former require free oxygen, the latter can react with the chemically bound oxygen from nitrates, sulphates etc. DO levels varied significantly $(\mathrm{p}<0.05)$ from 3.0 to $7.1 \mathrm{mg} / \mathrm{l}$ for surface water \& 5.0 to $11.6 \mathrm{mg} / \mathrm{l}$ for groundwater (Fig.8). At some spots DO of surface water has shown value below the minimum standards $(>6 \mathrm{mg} / \mathrm{l})$ set by WHO. The lowest level of DO in industrial phase-I \& II, sector-38 \& sector-52 indicates that industrial activities consume dissolved oxygen present in the water.

Chemical oxygen demand (COD): COD varied from 25 to $47.5 \mathrm{mg} / \mathrm{l}$ for surface water and from $10-16.6 \mathrm{mg} / \mathrm{l}$ for groundwater (Fig.9) which indicates organic pollution in water due to percolation of effluents containing soluble organic compounds. The levels of COD varied $(\mathrm{p}<0.05)$ significantly between groundwater $\&$ surface water but in groundwater in sector-35, $42 \& 44$ did not vary significantly. The value of COD in conjugation with BOD is helpful in knowing the toxic conditions and presence of biologically resistant organic substances as also reported by Rajkumar et al. (2003). COD is almost within acceptability range for most of the spots in groundwater \& surface water. 


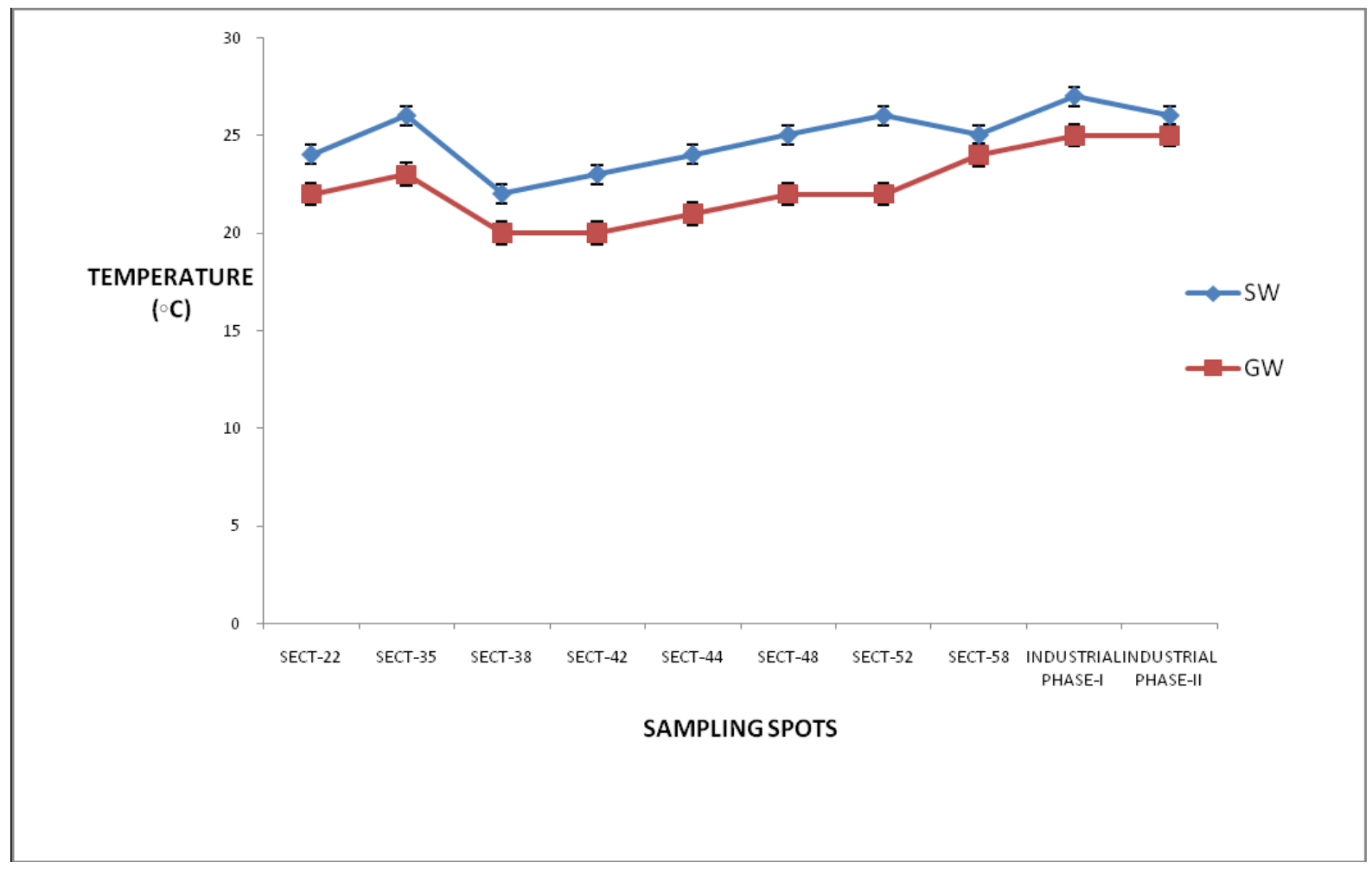

Figure 2. Value of Temperature $\left({ }^{\circ} \mathrm{C}\right)$ of Surface Water $(\mathrm{SW}) \&$ Groundwater $(\mathrm{GW})$ in Industry Dominating Sectors in Chandigarh

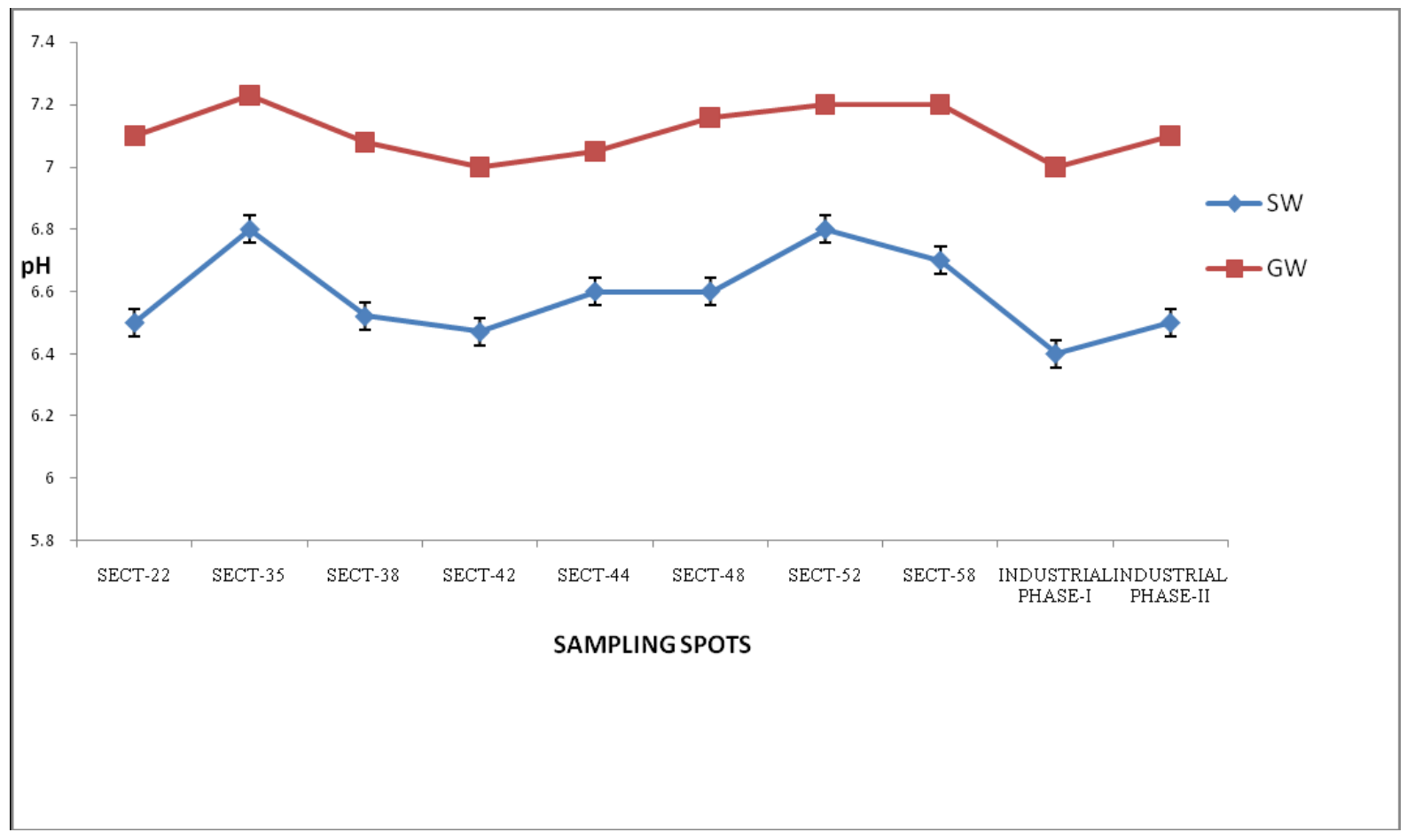

Figure 3. Value of $\mathrm{pH}$ of Surface Water (SW) \& Groundwater (GW) in Industry Dominating Sectors in Chandigarh 


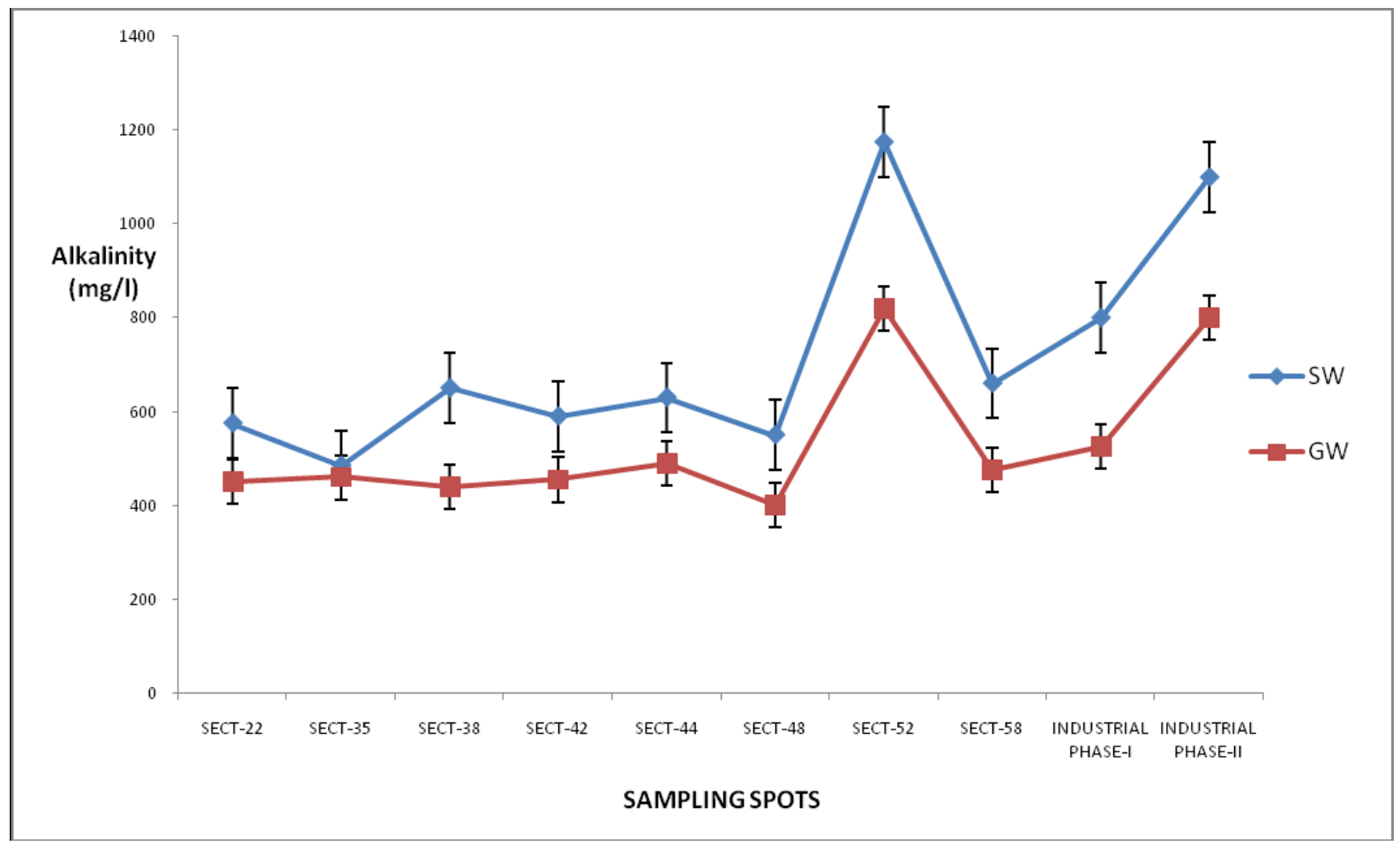

Figure 4. Value of Alkalinity of Surface Water (SW) \& Groundwater (GW) in Industry Dominating Sectors in Chandigarh

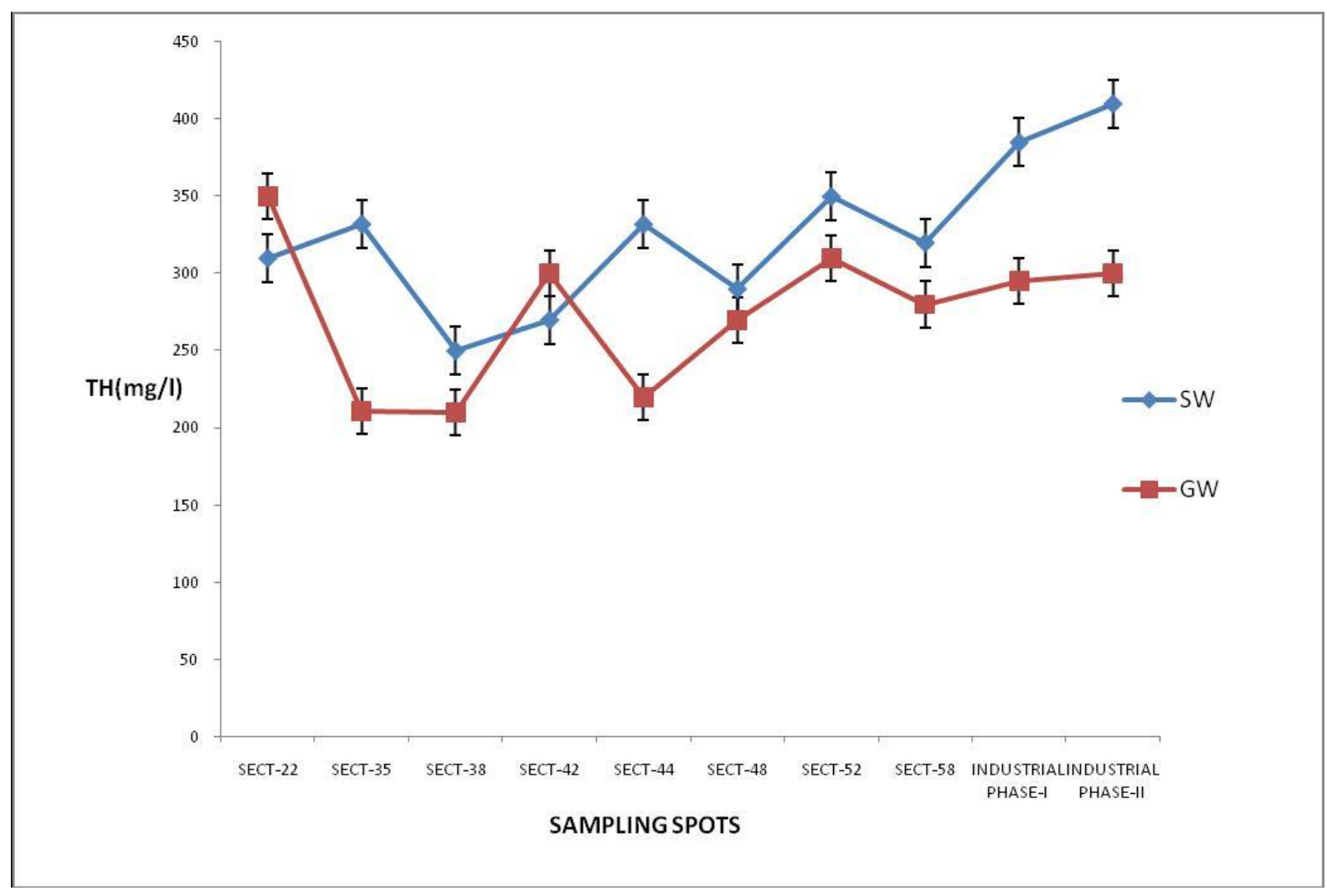

Figure 5. Value of Total Hardness (TH) of Surface Water (SW) \& Groundwater (GW) in Industry Dominating Sectors in Chandigarh 


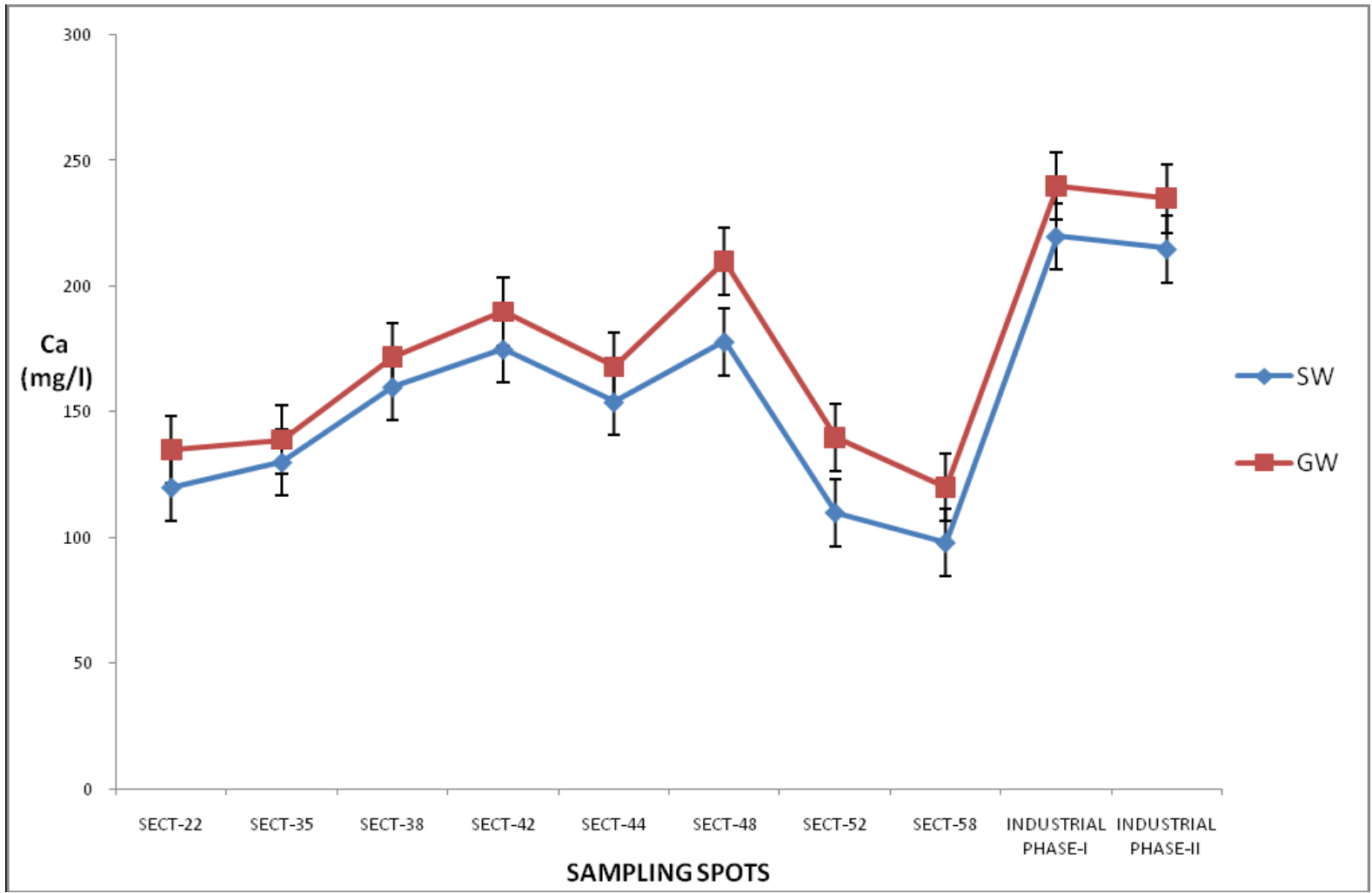

Figure 6. Value of Calcium (Ca) of Surface Water (SW) \& Groundwater (GW) in Industry Dominating Sectors in Chandigarh

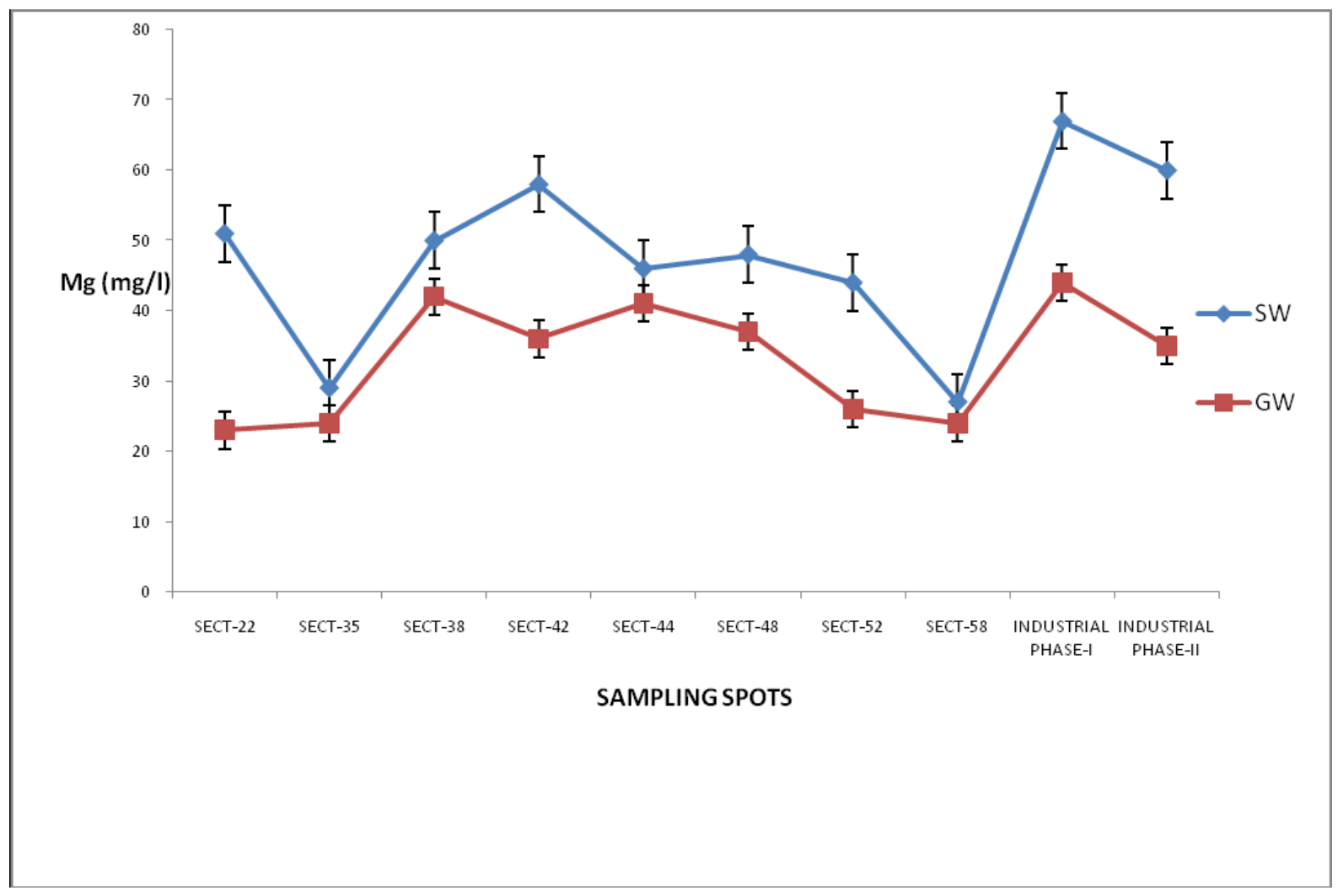

Figure 7. Value of Magnesium (Mg) of Surface Water (SW) \& Groundwater (GW) in Industry Dominating Sectors in Chandigarh 


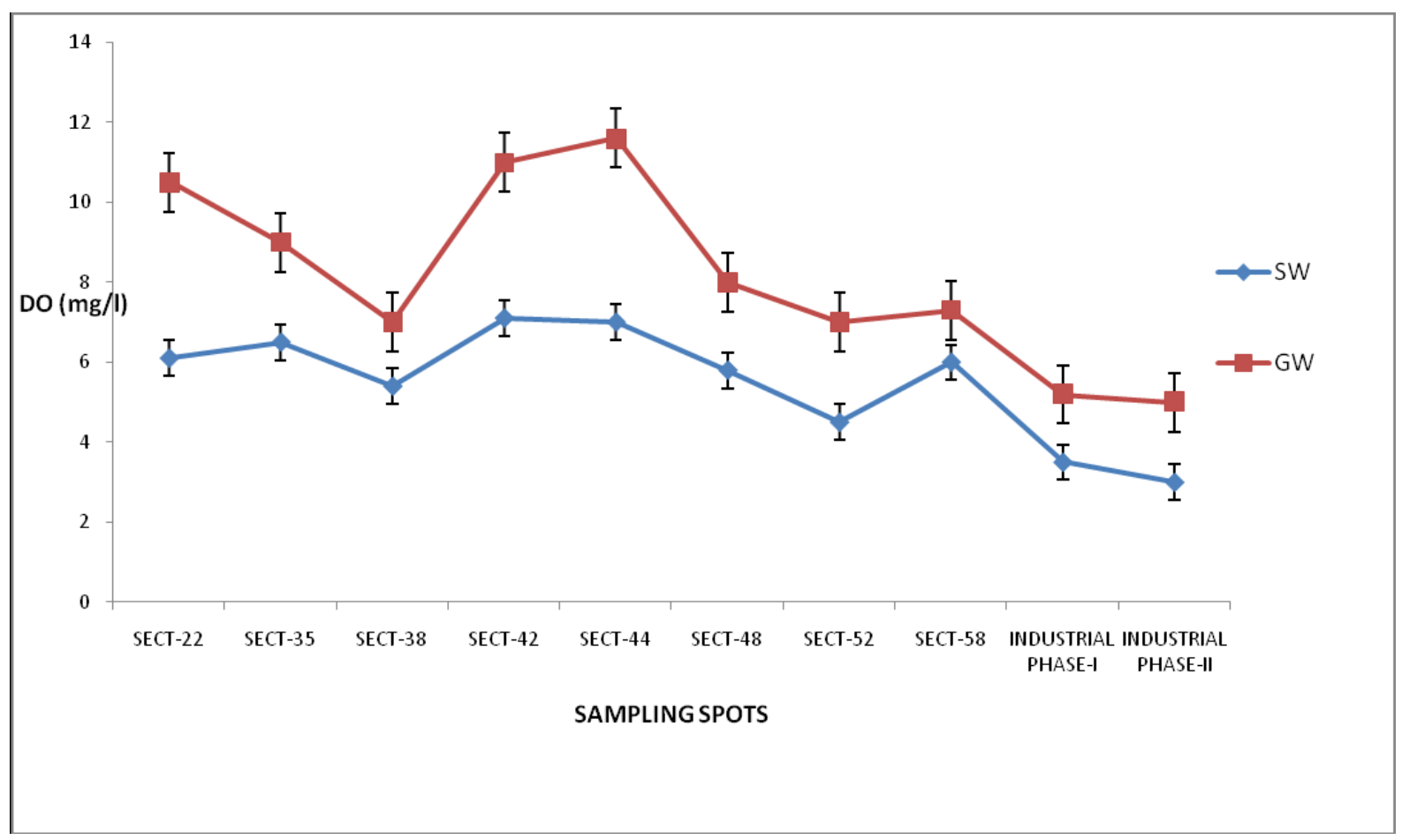

Figure 8. Value of Dissolved Oxygen (DO) of Surface Water (SW) \& Groundwater (GW) in Industry Dominating Sectors in Chandigarh

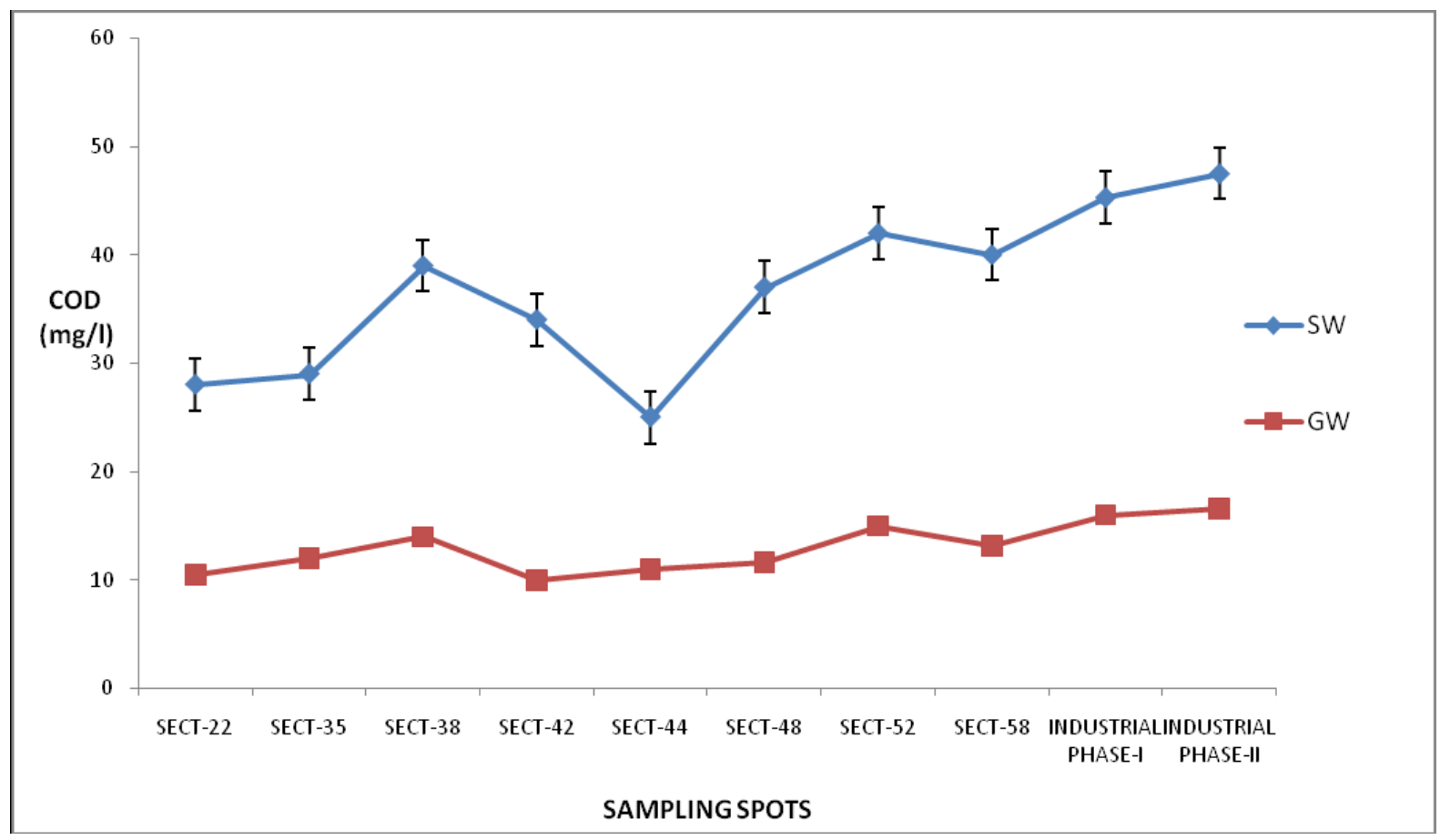

Figure 9. Value of Chemical Oxygen Demand (COD) of Surface Water (SW) \& Groundwater (GW) in Industry Dominating Sectors in Chandigarh

\section{Conclusion}

It is concluded from these findings that most of the parameters are not within the guidelines of WHO that may cause disastrous effects on public health \& environment if consumed 
directly without any treatment. High alkalinity, Total hardness, increased concentration of calcium \& magnesium may pose significant threat to consumer. There is no easy way to solve this problem but by proper treatment of industrial waste before discharge may reduce the risk of surface water \& groundwater pollution in this area. Though Government has made several legislations to control pollution, but all the anti-pollution law and measures become ineffective in the absence of proper monitoring system. This can be accomplished through regular monitoring by a central high powered group.

\section{Acknowledgement}

Authors are grateful to Post-graduate Government College, Sector-11, Chandigarh, India, for providing laboratory facilities for experimentation.

\section{References}

APHA. (2000). Standard methods for the examination of water and waste water.

Arain, M. B., Kazi, T. G., Jamali, M. K., Jalbani, N., Afridi, H. I., \& Shah, A. (2008). Total dissolved and bioavailble elements in water and sediment samples and their accumulation in Oreochromis mossambicus of polluted Manchar Lake. Chemosphere, 70(10): 1845-1856. http://dx.doi.org/10.1016/j.

Ayers, R. S., \& Westcot, D. W. (1994). Water quality for agriculture: FAO Irrigation and Drainage Paper 29. Rev. 1. pp. 1-130.

Dixit, S., \& Tiwari, S. (2008). Impact assessment of heavy metal pollution of Shahpura lake, Bhopal, India. International Journal of Environmental Research, 2(1): 37-42.

Durfer, C.M., \& Backer, E. (1964). Public water supplies of the three largest cities in the U.S. US Geological Survey water supply paper no. 1812, 364.

Gadgil, A. (1998). Drinking water in developing countries. Annual Review of Energy \& Environment, 23: 253-286. http://dx.doi.org/10.1146/annurev.energy.23.1.253.

Golubev, I. M., \& Zimin, V. P. (1994). On the standard of total hardness in drinking water. (In Russian.). Gig Sanit. 3: 22-23.

Kumar, R.N., Solanki, R., \& J.I. Nirmal Kumar. (2011). An Assessment of Seasonal Variation and Water Quality Index of Sabarmati River and Kharicut Canal at Ahmedabad, Gujarat. Electronic Journ of Environ, Agricul and Food Chem. 10(5): 2248-2261.

Lahiry, S.C. (1996). Impact on the environment due to industrial development in Chhatisgarh region of Madhya Pradesh. Finance India. 10 (1):133-136.

Memon, M., Soomro, M.S., Akhtar, M.S., \& Memon, K.S. (2011). Drinking water quality assessment in Southern Sindh (Pakistan). Environ Monit Assess. 177: 39-50. http://dx.doi.org/10.1007/s10661-010-1616-z. 


\section{Macrothink}

Muzalevskaya, L. S., Lobkovskii, A. G. \& Kukarina, N. I. (1993). Incidence of chole- and nephrolithiasis, osteoarthrosis, and salt arthropathies and drinking water hardness (In Russian.). Gigiena Sanitariia. 12: 17-20.

Pulikowski K., Kostrezewa S., Paluch J., \& Szewranski Sz. (2006). Stê magnezu orazwapnia $w$ odciekach drenarskich. J. Elementol, 11(4): 483-493.

Rajkumar, N. S., B. Nongbri \& Patwardhan , A. M. (2003). Physico-chemical and microbial analysis of Umiam (Barapani) lake water. Indian Journal of Environ. Prot. 23(6):633-639.

Sawyer, C. N., \& McCarty, P. I. (1967). Chemistry of sanitary engineers. McGraw- Hill. New York.

Sundaray, S.K., Nayak, B.B., \& Bhatta, D. (2009). Environmental studies on river water quality with reference to suitability for agricultural purposes: Mahanadi river esturine system, India - a case study. Environ Monit Assess. 155: 227-243. http://dx.doi.org/10.1007/s10661-008-0431-2.

WHO. (2004). Guidelines for drinking water quality. $3^{\text {rd }}$ ed. Vol.1. Recommendations, World Health Organization, Geneva. 